\title{
Person of the Issue: Carl Gustav Jung (1875-1961)
}

\author{
Ankit Patel
}

$\begin{array}{ll}\text { Born } & \text { 26 July 1875 } \\ & \text { Kesswil, Thurgau, Switzerland } \\ \text { 6 June 1961 (aged 85) } \\ \text { Died } & \begin{array}{l}\text { Küsnacht, Zürich, Switzerland } \\ \text { Alma mater }\end{array} \\ \text { University of Basel } \\ \text { Field } & \begin{array}{l}\text { Psychiatry, psychology, psychotherapy, } \\ \text { analytical psychology }\end{array}\end{array}$

Spouse Emma Jung

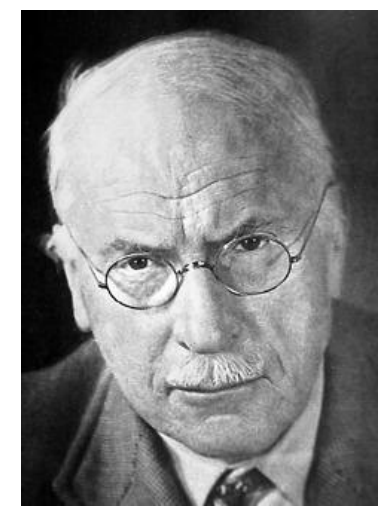

Carl Gustav Jung (1875-1961) had a significant contribution to the psychoanalytical movement and is generally considered as the prototype of the dissident through the impact of his scission and the amplification of the movement he created in his turn (analytical psychology).

Jung was the son of a Swiss reverend. He completed his medical studies, specialized in psychiatry and joined the staff of Burgholzli, the renowned psychiatric hospital in Zurich, run at that time by the famous Dr. Eugen Bleuler.

In 1902-1903 he attended a traineeship in Paris with Pierre Janet, and then returned to Zurich and he was called senior physician at Burgholzli.

It was in this context that Jung was introduced to Freud in 1907. Freud would be seduced by the prestige and personality of Jung and would soon see in him the spiritual son that could ensure the survival of psychoanalysis, so much so as Jung was not Jewish.

Intense, professional and friendship bonds form between the two, with an ambivalence dominated by the inclination of Jung to underestimate himself in comparison with Freud, the fervor of his devotion to the "father" of psychoanalysis and oneiric hostility (emphasized by Freud in the common interpretation of dreams).

Jung had a swift ascension in the hierarchy of psychoanalysis. He became the editor of Jahrbuch.

${ }^{1}$ Cilinical Psychology, Sardar Parel University, Gujarat

(C) 2015 A Patel; licensee IJIP. This is an Open Access Research distributed under the terms of the Creative Commons Attribution License (http://creativecommons.org/licenses/by/2.0), which permits unrestricted use, distribution, and reproduction in any Medium, provided the original work is properly cited. 
Person of the Issue: Carl Gustav Jung (1875-1961)

In 1908, he traveled to the United States and in 1910 he became the first president o the International Association of Psychoanalysis.

The reluctance of Jung towards the Freudian theory referred to the role of sexuality in the psychic development. In fact, Jung never completely embraced the sexual theory of Freud.

Since 1912 he became more and more distant in his writings, which would cause a scission materialized in 1914 by his resignation from all the positions he already held.

He married Emma Rauschenbach in 1903. They had five children. Even though he remained married to Emma till her death, he had several affairs with other women, the most notable of whom were Sabina Spielrein and Toni Wolff.

TIME LINE

\begin{tabular}{|c|c|}
\hline Years & Happenings \\
\hline 1875 & $\begin{array}{l}\text { Jung is born in in Kesswill, Switzerland, son of a Reformed Protestant pastor, } \\
\text { Johann Paul Jung, and Emilie Preiswerk. }\end{array}$ \\
\hline 1895 & Jung enters Basel University to study science and medicine. \\
\hline 1896 & Jung's father dies. \\
\hline 1900 & $\begin{array}{l}\text { Jung graduates with a M.D. from the University of Basel and is appointed } \\
\text { assistant at the Burgholzli Psychiatric Hospital, Zurich, under Professor Eugen } \\
\text { Bleuler. }\end{array}$ \\
\hline $\begin{array}{l}1900- \\
1909\end{array}$ & Jung works at the Burgholzli Mental Hospital in Zurich. \\
\hline 1902 & $\begin{array}{l}\text { Jung gets his Ph.D. at the University of Zurich with a doctoral dissertation On } \\
\text { the Psychology and Pathology of So-Called Occult Phenomena. }\end{array}$ \\
\hline 1903 & Jung marries Emma Rauschenberg. The get five children in the course of time. \\
\hline $\begin{array}{l}1905- \\
1913\end{array}$ & Jung lectures in psychiatry at the University of Zurich. \\
\hline 1906 & $\begin{array}{l}\text { Jung initiates letter correspondance with Sigmund Freud and visits him next year } \\
\text { in Vienna. }\end{array}$ \\
\hline 1907 & $\begin{array}{l}\text { Jung's first meeting with Freud. He writes the work The Psychology of Dementia } \\
\text { Praecox. }\end{array}$ \\
\hline 1909 & Jung resigns from Burgholzli. He visits USA with Freud. \\
\hline 1909 & $\begin{array}{l}\text { Jung also opens his private practice of psychoanalysis in Kuessnacht - he runs it } \\
\text { enthusiastically till he dies. }\end{array}$ \\
\hline 1910 & $\begin{array}{l}\text { Jung is elected President of International Psychoanalytic Association. He writes } \\
\text { Symbols of Transformation. Lectures at Fordham University. }\end{array}$ \\
\hline 1912 & $\begin{array}{l}\text { Jung declares he is scientifically independent of Freud and publishes Neue } \\
\text { Bahnen der Psychologie. }\end{array}$ \\
\hline 1913 & Jung resigns as President. His final break with Freud. \\
\hline 1916 & Jung publishes La structure de l'inconscient. \\
\hline 1917 & Jung publishes Die Psychologie der unbewussten Prozesse. \\
\hline 1919 & Jung's first use of the term archetype (in Instinct und Unbewusstes). \\
\hline 1921 & Jung publishes Psychologische Typen (Psychological Types). \\
\hline 1923 & Jung starts the building of his "tower" in Bollingen. \\
\hline 1923 & Jung visits Pueblo Indians in North America. \\
\hline
\end{tabular}




\begin{tabular}{|c|c|}
\hline 1925 & Jung's study trip to the Elgonyi of Mount Elgon in East Africa. \\
\hline 1929 & Jung's Commentary on the Taoist text The Secret of the Golden Flower. \\
\hline 1931 & Jung publishes Seelenprobleme der Gegenwart. \\
\hline $\begin{array}{l}1932- \\
1940\end{array}$ & $\begin{array}{l}\text { Jung works as a professor of psychology at the Federal Polytechnical University } \\
\text { in Zurich. }\end{array}$ \\
\hline 1934 & $\begin{array}{l}\text { Jung publishes Wirklichkeit der Seele. He also begins series of seminars on } \\
\text { Nietzsche's Zarathustra. President (until 1939) of International Society for } \\
\text { Medical Psychotherapy. }\end{array}$ \\
\hline 1935 & Jung's Tavistock Lectures, London, on "Analytical Psychology". \\
\hline 1937 & Jung's Terry Lectures, Yale University, on "Psychology and Religion". \\
\hline 1937 & Jung's study trip to India. \\
\hline 1941 & Jung publishes Essays on a Science of Mythology with Karl KerÃ@nyi. \\
\hline $1944-$ & $\begin{array}{l}\text { Jung becomes professor of medical psychology at the University of Basel, and } \\
\text { his Psychology and Alchemy is published. }\end{array}$ \\
\hline 1945 & Jung publishes Nach der Katastrofe. \\
\hline 1948 & Founding of C.G. Jung Institute, Zurich. \\
\hline 1950 & Jung publishes Aion - FÃ anomenologie des Selbsts. \\
\hline 1951 & Jung's lecture "On Synchronicity". \\
\hline 1952 & Jung publishes Antwort fÃ $1 / 4$ r Job (Answers to Job). \\
\hline 1955? & His Mysterium Coniunctionis. \\
\hline 1957 & Jung publishes Gegenwart und Zukunft. \\
\hline 1961 & $\begin{array}{l}\text { Jung dies at his home in Kusnacht, near Zurich, at the age of } 85 \text {, after a short } \\
\text { illness. }\end{array}$ \\
\hline
\end{tabular}

"Thank God I am Jung and not Jungian" (C.G. Jung)

\section{CARL JUNG WORKS*}

1. Memories, Dreams, Reflections

2. The Red Book: A Reader's Edition (Philemon)

3. The Portable Jung (Portable Library)

4. Modern Man in Search of a Soul

5. The Archetypes and The Collective Unconscious (Collected Works of C.G. Jung Vol.9 Part 1)

6. Synchronicity: An Acausal Connecting Principle. (From Vol. 8. of the Collected Works of C. G. Jung) (Jung Extracts)

7. Psychological Types (The Collected Works of C. G. Jung, Vol. 6) (Bollingen Series XX)

8. The Basic Writings of C. G. Jung (Modern Library)

9. Psychology and Alchemy (Collected Works of C.G. Jung Vol.12)

10. Mysterium Coniunctionis (Collected Works of C.G. Jung Vol.14)

11. Aion: Researches into the Phenomenology of the Self (Collected Works of C.G. Jung Vol.9 Part 2)

12. Four Archetypes: (From Vol. 9, Part 1 of the Collected Works of C. G. Jung) (Jung Extracts)

13. Answer to Job: (From Vol. 11 of the Collected Works of C. G. Jung) (Jung Extracts) 
Person of the Issue: Carl Gustav Jung (1875-1961)

14. Symbols of Transformation (Collected Works of C.G. Jung Vol.5)

15. Psychology and Religion (The Terry Lectures Series)

16. Alchemical Studies (Collected Works of C.G. Jung Vol.13)

17. The Development of Personality (Collected Works of C.G. Jung Vol.17)

18. Jung contra Freud: The 1912 New York Lectures on the Theory of Psychoanalysis (Bollingen Series (General))

19. The Undiscovered Self: With Symbols and the Interpretation of Dreams (Jung Extracts)

20. The Psychology of the Transference

21. Dreams: (From Volumes 4, 8, 12, and 16 of the Collected Works of C. G. Jung) (Jung Extracts)

22. Analytical Psychology

23. Analytical Psychology: Its Theory \& Practice (The Tavistock Lectures)

24. Essays on a Science of Mythology (With Carl Kerenyi)

25. Two Essays on Analytical Psychology (Collected Works of C.G. Jung Vol.7)

26. The Symbolic Life: Miscellaneous Writings (The Collected Works of C. G. Jung, Volume 18)

*All the works are available at

http://astore.amazon.com/freudandpsychoan?node=3\&page $=1$

\section{REFERENCE}

1. Carl Jung Resources, (2015) Carl Jung Biography, http://www.carljung.net/biography.html

2. Carl Jung Resources, (2015) http://www.carl-jung.net/timeline.html

3. Carl Jung, http://en.wikipedia.org/wiki/Carl_Jung

4. Polly Young-Eisendrath. The Cambridge Companion To Jung. Cambridge University, 2010. pp. 24-30.

5. Anthony Lightfoot. A Parallel of Words. AuthorHouse, 2010. p. 90

6. Jung's Individuation process Retrieved on 2009-2-20

7. Aniela Jaffe, foreword to Memories, Dreams, Reflections, p. x.

8. Dunne, Clare (2002). "Prelude". Carl Jung: Wounded Healer of the Soul: An Illustrated Biography. Continuum International Publishing Group. p. 3. ISBN 978-0-8264-6307-4.

9. Lachman, Gary (2010). Jung the Mystic. New York: Tarcher/Penguin. p. 258. ISBN 9781-58542-792-5.

10. Hanegraaff 1993, p. 224.

11. Dunne, Claire (2002). Carl Jung: Wounded Healer of the Soul: An Illustrated Biography. Continuum. p. 5.

12. Memories, Dreams, Reflections, p. 8.

13. Corbett, Sara (16 September 2009). "The Holy Grail of the Unconscious". The New York Times. Retrieved 2009-09-20.

14. Stepp, G. "Carl Jung: Forever Jung". Vision Journal. Retrieved 19 December 2011.

15. Memories, Dreams, Reflections. pp. 33-34. 